\title{
Seminoma and sertolioma in non-cryptorchid dog - case report
}

\author{
Seminoma e sertolioma em cão não criptorquida - relato de caso \\ Guilherme Mantuani Silva ${ }^{\mathbb{D}}$, Isabela Cristina de Oliveira ${ }^{1} \mathbb{D}^{\mathbb{B}}$, Rodrigo Samuel de Toledo ${ }^{\mathbb{D}}$,

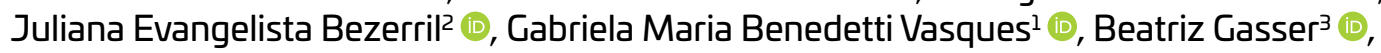 \\ Paulo Fernandes Marcusso ${ }^{4}$, Isaac Romani ${ }^{\star}$, (i)
}

\begin{abstract}
The most common testicular neoplasms in dogs are seminoma, leydigocytoma and sertolioma, affecting middle-aged and elderly dogs, where cryptorchidism is a predisposing factor, as well as some breeds. It can occur alone or, less frenquently, concurrently, generally affecting the same testicle. This study aimed to report the case of a non-cryptorchid 14-year-old mixed breed dog diagnosed with seminoma and sertolioma, each in a testicle. The animal showed an increase in scrotal volume, with no changes in other clinical parameters on physical examination. On ultrasound examination, it was possible to observe alterations suggestive of neoplasia in both testicles and prostatic alteration suggestive of benign prostatic hyperplasia. Complementary blood count and biochemical tests were performed and, as treatment, orchiectomy was performed. Fragments were collected from both testicles and sent for histopathological examination. Microscopy of the left testicle showed the presence of round cells, multiple and evident nucleoli, cells in different phases of mitosis and binucleation, these changes being compatible with seminoma. In contrast, in the right testicle, spindle and elongated cells (pseudo-lobular) were observed, presence of long cytoplasmic projections with rounded ovoid nucleus, spindle cells and degeneration of seminiferous tubules, compatible with sertolioma. It was observed that physical examination associated with ultrasound was efficient to detect the presence of neoplasms, being validated by histopathological examination. Orchiectomy was an assertive treatment indicated for this case.
\end{abstract}

KEYWORDS: Histopathological; Neoplasia; Reproductive system; Testicle.

RESUMO: As neoplasias testiculares mais comuns em cães são o seminoma, leydigocitoma e o sertolioma, acometendo cães de meia idade e idosos, com predisposiçáo racial e animais criptorquidas, podendo ocorrer isoladamente, ou concomitantemente, porém com menor frequência. Esse trabalho objetivou relatar o caso de um cão, SRD, 14 anos, não criptorquida diagnosticado com seminoma e sertolioma em testículos distintos. $\mathrm{O}$ animal apresentou aumento do volume testicular bilateral, sem alterações nos demais parâmetros clínicos ao exame físico. Ao exame ultrassonográfico foi possível observar alteraçóes sugestivas de neoplasia para ambos os testículos e alteração prostática sugestiva de hiperplasia prostática benigna. Foram realizados exames complementares de hemograma e bioquímico e como tratamento a realização de orquiectomia. Fragmentos foram coletados de ambos os testículos e enviados para análise histopatológica. A microscopia do testículo esquerdo, evidenciou a presença de células arredondadas, nucléolos múltiplos e evidentes, células em diferentes fases de mitose e binucleação, alteração compatíveis de seminoma. Em contrapartida, no testículo direito foi observado a presença de células fusiformes e alongadas (pseudo-lobular), presença de longas projeções citoplasmáticas com núcleo ovóide arredondado, células fusiformes e degeneração dos túbulos seminíferos compatíveis de sertolioma. Observou-se que o exame físico associado ao ultrassonográfico foi eficiente para detectar a presença das neoplasias e isto foi validado pelo exame histopatológico. A realização de orquiectomia foi tratamento assertivo indicado para este caso.

PALAVRAS-CHAVE: Histopatológico; Neoplasia; Sistema Reprodutor; Testículo.

\section{INTRODUCTION}

Testicular neoplasms are the most common disorders in the reproductive tract of male dogs, corresponding to approximately $90 \%$ of the reports of reproductive neoplasms and representing the second most common location observed in the species. Due to factors such as early orchiectomy, absence of histopathological exams, lack of periodic veterinary follow-up and the fact that they are usually necropsy findings, it is difficult to assess the real incidence of these neoplasms (FOSTER, 2016).

Testicular tumors are classified mainly according to their cellular origin, in: germ cell tumors (seminomas, teratomas 
and embryonic carcinomas), tumors of stroma and cord sex cells (Sertoli cell tumor, Leydig cell tumor and undifferentiated intermediary tumors), vascular tumors, mesotheliomas and multiple primary tumors (CATOI et al., 2008). Testicular neoplasms affect middle-aged and elderly dogs, with an average age of $11.46 \pm 3.47$ years (SANTOS et al. 2000), the most predisposing breeds are Boxer, German shepherd, Weimaraner, Afghan hound and Shetland sheepdog and the least predisposing are Dachshund and mixed breed dogs (STAUT; ASSEF; CIRIO, 2007).

Testicular neoplasms in the canine species can develop in normal testicles, but they are more prone to appear in cryptorchid testicles (GRIECO et al., 2008). The most common are Leydig cell tumors, seminomas and sertoliomas, the first being the most frequent. It is also observed that approximately $40 \%$ of dogs that develop testicular neoplasms present more than one type of testicular tumor (STAUT; ASSEF; CIRIO, 2007). However, it is not commonly reported in the literature the presence of different neoplasms affecting different testicles in a non-cryptorchid animal. In view of the above, the present study aimed to report the case of a non-cryptorchid dog presenting bilateral testicular neoplasms.

\section{CASE REPORT}

A 14-year-old male mixed breed dog weighing $17.5 \mathrm{~kg}$ was attended at the Veterinary Clinic of UNINGÁ - Ingá University Center. On physical examination, the animal presented all vital parameters within the normal range, on inspection and palpation an increase in volume of hard consistency was noted in the left testicle. According to the owners, the increase occurred within 6 to 8 months progressively, a circumference of $24.8 \mathrm{~cm}$ of the scrotum was measured, the right testicle did not present any noteworthy changes.

Complementary blood tests, biochemical tests and ultrasound assessment of the abdominal region and scrotum were requested. $3 \mathrm{ml}$ of blood were collected through the jugular venipuncture, in which $0.5 \mathrm{ml}$ were stored in a micro tube of dipotassium ethylene diamine tetra acetic acid (EDTA K2) and $2.5 \mathrm{ml}$ in a dry tube for biochemical analyzes. The hematological evaluation was carried out at the Laboratory of Veterinary Clinical Pathology at UNINGÁ. The erythrogram and total leukocyte and platelet count were performed using the BC2800Vet automatic counter (Mindray United States). For differential leukocyte count and qualitative assessment of cells, stained blood smears were made using the quick dye for hematology (Instant-Prov - NEWPROV), being analyzed under 1000x magnification light microscopy (Eclipse E200MV - NIKON).

Biochemical assessments were performed using the semi-automatic biochemical analyzer model Bio-200S $\left(\right.$ Bioplus $^{\circledR}$ ) using commercial kits (Analisa ${ }^{\circledR}$ ) to assess the serum concentration of alanine aminotransferase (ALT) and creatinine. The blood test showed that all results were within the normal range, however, in the biochemical analysis there was an increase in the hepatic enzyme ALT with a value of $157.0 \mathrm{IU} / \mathrm{L}$ (21.0 to $73.0 \mathrm{IU} / \mathrm{L})$, yet the animal did not show any clinical symptoms associated with the increase in this enzyme.

The ultrasound evaluation was performed at the Diagnostic Imaging Sector of the Veterinary Clinic of UNINGÁ using the equipment Toshiba Istyle - Nemio XG. The ultrasound evaluation of the abdominal cavity did not reveal any changes, except for the prostate, presenting regular contours, bilobed aspect, measuring approximately $4.40 \mathrm{~cm}$ in length and $2.54 \mathrm{~cm}$ in height in longitudinal plane, with slightly heterogeneous parenchyma with the presence of cysts, suggestive of benign prostatic hyperplasia as can be seen in (Figure 1). However, in the testicular ultrasound examination (Figure 2b) decreased dimensions were observed in the right testicle (length: $2.61 \mathrm{~cm}$, width: $1.32 \mathrm{~cm}$, depth: $5.37 \mathrm{~cm}$ ), with slightly heterogeneous parenchyma, suggestive of nodules / neoplasia and regular testicular mediastinum. In the left testicle (Figure 2a), markedly increased dimensions (length: $8.90 \mathrm{~cm}$, width: $4.90 \mathrm{~cm}$, depth: $1.37 \mathrm{~cm}$ ), heterogeneous parenchyma with hypoechogenic areas and absence of testicular mediastinum were noted, suggestive of neoplasia.

After the ultrasound diagnosis, the animal was referred for surgical treatment by pre-scrotal orchiectomy at the Small Animal Surgery Sector of UNINGÁ. As pre-anesthetic medication, acepromazine $(0.05 \mathrm{mg} / \mathrm{kg})$ and morphine $(0.3 \mathrm{mg} / \mathrm{kg})$ were administered intramuscularly, followed by induction with ketamine $(5 \mathrm{mg} / \mathrm{kg})$ and diazepam $(0.2 \mathrm{mg} / \mathrm{kg})$ intravenously and local anesthetic in the incision line, with lidocaine $(1 \mathrm{ml})$. As postoperative medication, meloxicam $(0.1 \mathrm{mg} / \mathrm{kg})$ was administered subcutaneously and dipyrone $(25 \mathrm{mg} / \mathrm{kg})$ intramuscularly.

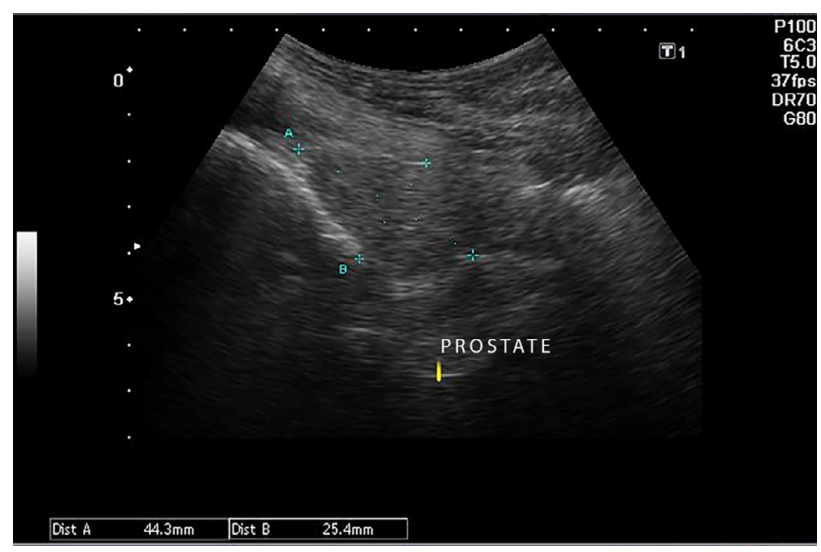

Figure 1. Sagittal sonogram (8 MHZ, B-mode) of the prostate of a mixed breed dog, 14 years old, with regular contours, bilobed aspect, slightly heterogeneous parenchyma, with the presence of cysts and measuring approximately $4.40 \mathrm{~cm}$ length and $2.54 \mathrm{~cm}$ height in longitudinal plane. 


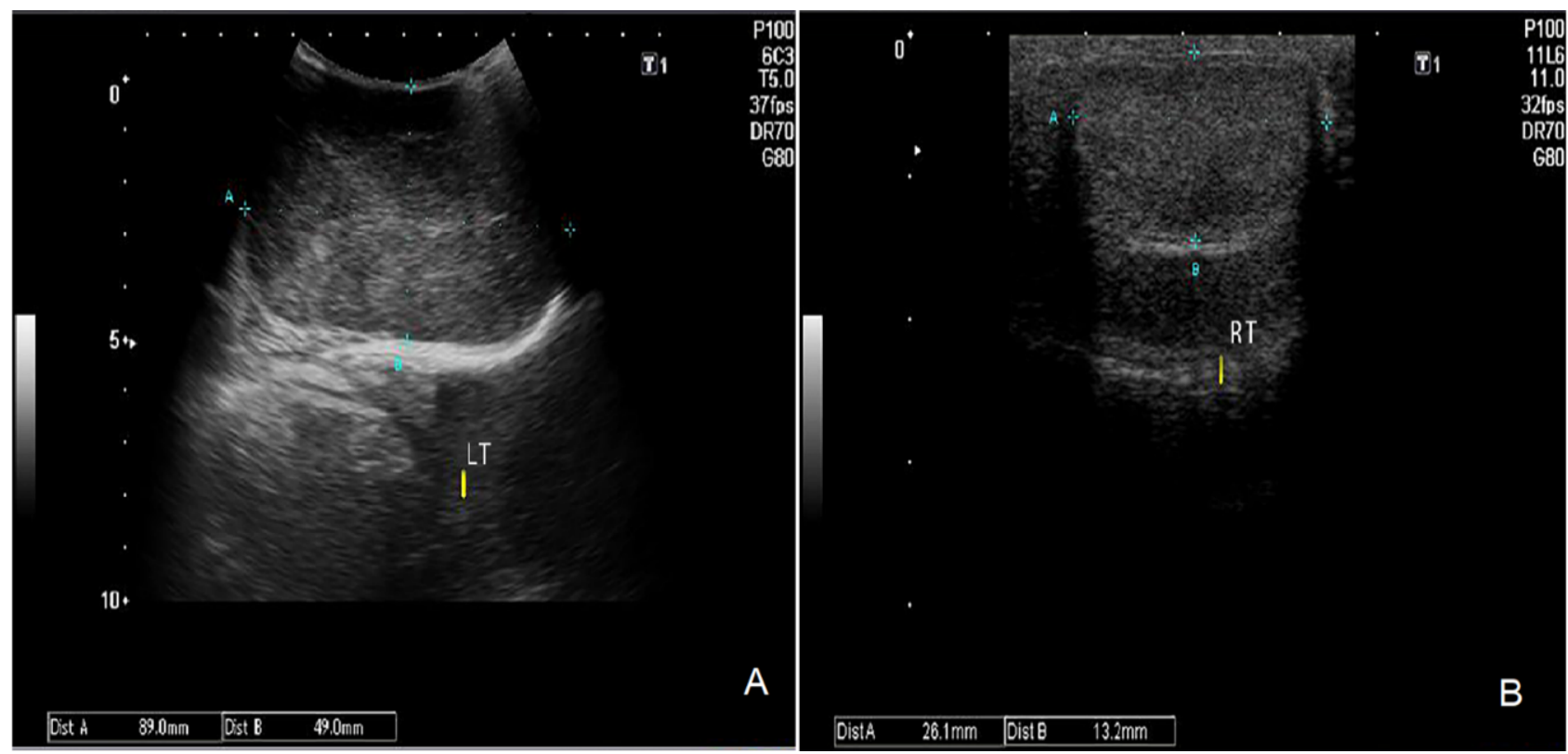

Figure 2. Sonogram (A - 8 MHZ, B - 12 MHZ, B-mode) of testicles of mixed breed dog, 14 years old. (A) LT - Left testicle with markedly increased dimensions, length: $8.90 \mathrm{~cm}$, width: $4.90 \mathrm{~cm}$, depth: $1.37 \mathrm{~cm}$; (B) RT - Right testicle with reduced dimensions, length: $2.61 \mathrm{~cm}$, width: $1.32 \mathrm{~cm}$, depth: $5.37 \mathrm{~cm}$.

After the surgical procedure, testicular measurements were taken using a caliper and digital precision scale. The data obtained are shown in Table 1.

Once these characteristics were collected, incisional biopsies in the testicles were performed, obtaining fragments with both macroscopically normal and altered testicular tissue, being packed in previously identified vials containing $10 \%$ formaldehyde for fixation for 48 hours, respecting the volume of 1 part of tissue for 9 parts of formalin.

Subsequently, the testicle fragments were stored in cassettes for processing, where they were dehydrated, diaphanized, included in paraffin, cut between three and five micrometers $(\mu \mathrm{m})$, laminated and stained using hematoxylin and eosin $(\mathrm{HE})$ techniques for later evaluation under an optical microscope Eclipse E200 - Nikon ${ }^{\circledR}$, at the UNINGÁ Animal Pathology Sector. The slides containing the testicular fragments were evaluated and the histopathological changes found were classified (FOSTER, 2016).

The histopathological examination showed, in the left testicle, rounded cells, multiple and evident nucleoli, cells in different phases of mitosis and binucleation (Figure 3a), these histological characteristics found are suggestive of seminoma. The right testicle, on the other hand, presented fusiform and elongated cells, which were arranged in a pseudo-lobular structure, in addition to the presence of long cytoplasmic projections with rounded ovoid nucleus, spindle cells and degeneration of seminiferous tubules (Figure $3 b$ ), these changes are suggestive of sertolioma.

After six months, the animal returned to the Veterinary Clinic of UNINGÁ for a new evaluation and monitoring of the case. On physical examination, all parameters were found
Table 1. Testicular measurements obtained after orchiectomy of a non-cryptorchid 14-year-old mixed breed dog with testicular neoplasia.

\begin{tabular}{l|c|c} 
Variables evaluated & Left Testicle & Right Testicle \\
\hline Lenght $(\mathrm{cm})$ & 8.29 & 2.48 \\
\hline Width $(\mathrm{cm})$ & 5.91 & 1.56 \\
\hline Thickness $(\mathrm{cm})$ & 5.55 & 1.21 \\
\hline Volume $\left(\mathrm{cm}^{3}\right)$ & 142.21 & 2.44 \\
\hline Mass $(\mathrm{g})$ & 159.26 & 3.73 \\
\hline
\end{tabular}

to be within normal limits, and further complementary tests were requested: blood count, creatinine and ALT, abdominal ultrasound and chest radiographic examination to search for possible metastasis.

The blood count and biochemical exams showed normal values, noting the return to normal levels of the liver enzyme ALT of 54.0 IU/L. In the ultrasound (Figure 4) and radiographic exams, no significant alterations were found, except for the same prostatic alterations observed previously compatible with benign prostatic hyperplasia, however a reduction in size was observed when compared to the previous exam, with the measurements being $2.20 \mathrm{~cm}$ in length and $1.68 \mathrm{~cm}$ in height in longitudinal plane.

\section{DISCUSSION}

After the histopathological examination of the testicles, two distinct neoplasms were observed, the seminoma being observed in the left testicle and sertolioma in the right testicle. Testicular neoplasms are common in domestic dogs; however, 


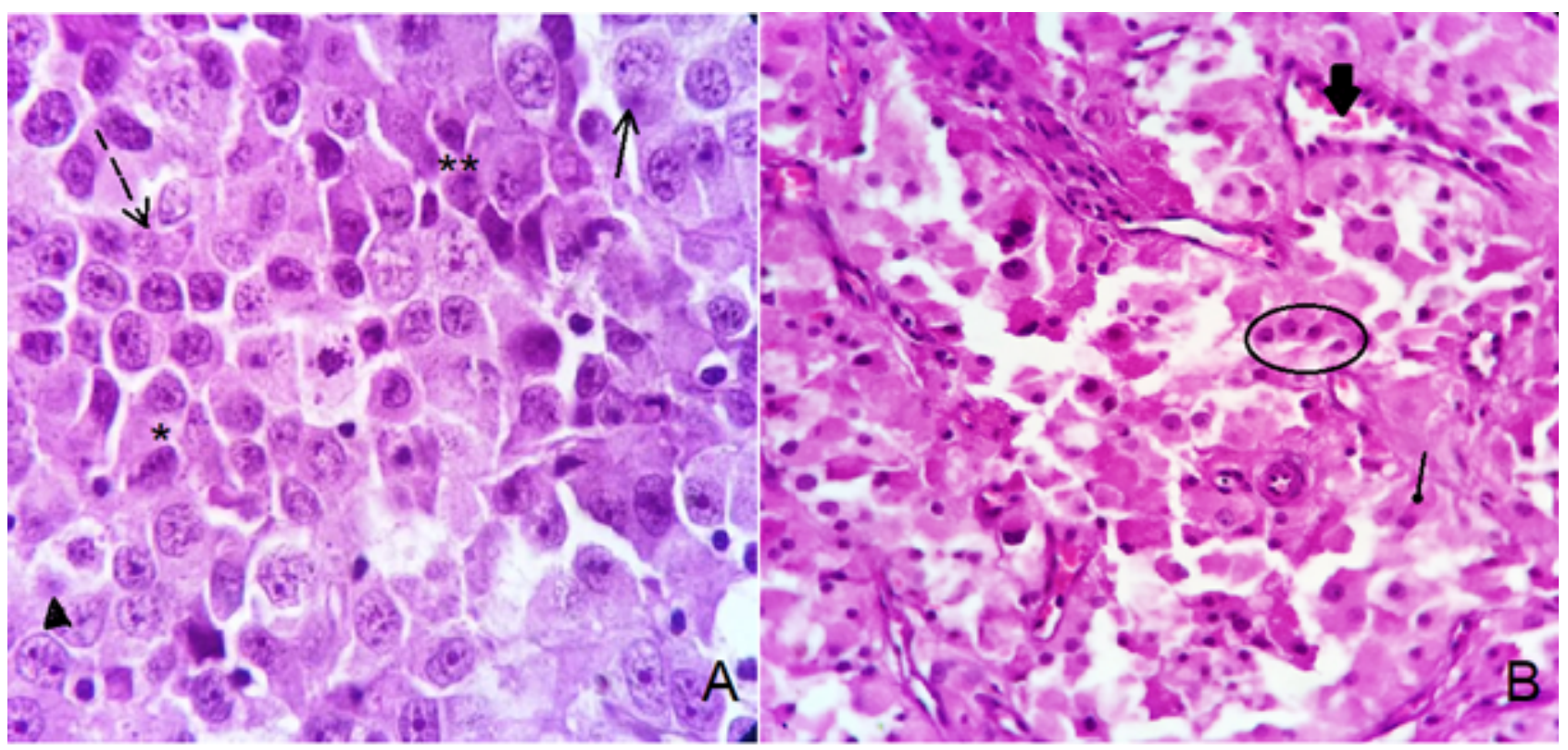

Figure 3. a) Seminoma, presence of round cells (continuous arrow), binucleation (arrowhead), different phases of mitosis ( ${ }^{*}$, $\left.{ }^{\star \star}\right)$, evident multiple nucleoli (discontinuous arrow) (HE, 100x objective) are observed. b) Sertolioma, spindle cells (arrow with tip in eclipse), ovoid nucleus (eclipse) and degeneration of seminiferous tubules (short arrow) (HE, 40x objective).

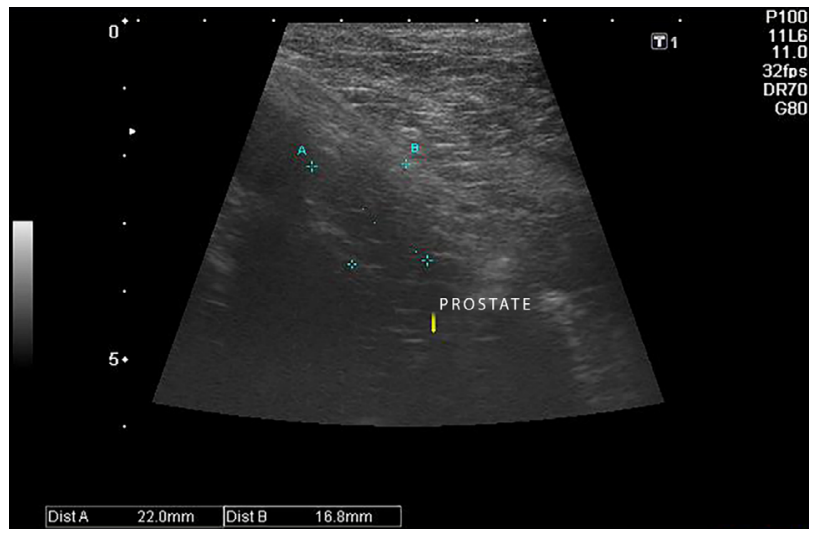

Figure 4. Longitudinal sonogram (8 MHZ, B-mode) of the prostate of a mixed breed dog, 14 years old, presenting small cysts in parenchyma and measuring $2.20 \mathrm{~cm}$ length and $1.68 \mathrm{~cm}$ height in longitudinal plane.

their incidence is difficult to estimate due to early orchiectomies and the low frequency of histopathological exams. Some predisposing factors are well defined, such as advanced age, breed, environmental carcinogens and unilateral and bilateral cryptorchidism, with seminoma and sertolioma being the most common neoplasms (COSTA, 2016; HENRIQUE et al., 2016; LOPES et al., 2019; NETA et al., 2019). In this report, the animal presented the two most common types of testicular neoplasms, age of 14 years as an important predisposing factor, but did not presented cryptorchidism.

The occurrence of sertolioma and seminoma in a bilateral cryptorchid dog has been reported which the ultrasound examination revealed the right testicle with preserved dimensions, parenchyma suggestive of normality, the left testicle with enlarged dimensions, heterogeneous and vascularized parenchyma, suggestive of neoplasia and prostatic hyperplasia, with heterogeneous parenchyma and anechoic areas (COSTA, 2016). After orchiectomy and histopathological evaluation, the presence of seminoma in the right testicle and sertolioma in the left was verified. Differing in the macroscopic presentation of this report, in which the testicle affected by seminoma increased in size, while the contralateral affected by sertolioma maintained its dimensions. Therefore, the macroscopic presentation of neoplasms does not appear to have a well-defined pattern.

Bilateral seminoma and leydigocytoma have been reported in non-cryptorchid dogs (SILVA et al., 2014; VISCONE et al., 2016). Both cases, as in the case presented, were mixed breed dogs, advanced age, who came to the service with testicular enlargement.

Seminomas have their origin in the germ cells of the testicular sperm epithelium and are common in dogs, as well as sertolioma. The authors mention that, among the predisposing factors are age and cryptorchidism, however, in approximately $70 \%$ of seminoma cases, its development occurs in scrotal testicles, as in the reported case, and only one third in cryptorchid testicles. (BOMFIM et al., 2016; COSTA, 2016; LOPES et al., 2019; NETA et al., 2019).

Seminomas usually occur unilateral and uninodular, however $10 \%$ to $18 \%$ are bilateral and multinodular, being more common in the right than in the left testicle (MORRIS; DOBSON, 2001), in this report the seminoma was unilateral and uninodular in the left testicle. It was observed that, in the first visit, the dog did not show clinical signs that indicated a possible testicular neoplasia, however, on palpation, a 
change in size was observed in the left testicle. At follow-up, after complementary examinations, the dog did not present any metastasis due to testicular neoplasms, which corroborates with other reports (CIAPUTA et al., 2012; GRIECO et al., 2008). These authors describe that seminomas are rarely malignant, do not produce hormones, and usually do not show clinical signs, however in some cases pain is noticed due to the pressure created by the growth of the tumor.

Sertoliomas originate from support cells located in seminiferous tubules, being the third most common neoplasm in males of the canine species, with reports in other species as well. They occur more frequently in cryptorchid animals, unilaterally, and may be bilateral in cases of bilateral cryptorchidism (COSTA, 2016; GRIECO et al., 2008; MADUREIRA et al., 2017) in contrast to that described in this report. Around 24\% to 57\% of animals affected by sertolioma have a hormonal imbalance, developing hyperestrogenism, resulting in paraneoplastic feminization syndrome. The most common clinical signs are apathy, depression, gynecomastia, alopecia, contralateral testicular atrophy, hypopigmentation, penile atrophy, pendulous foreskin, prostatic cysts and abscesses and even granulocytic anemia and thrombocytopenia (CIAPUTA et al., 2012; MADUREIRA et al., 2017; MARQUES et al., 2020). However, the animal in this report did not present any of these clinical signs.

Despite causing problems, sertolioma has a benign behavior and its metastasis rate is less than $10 \%$, being more common in lumbar and iliac lymph nodes, however cases of metastasis in organs such as liver, lung, spleen have also been reported, and may also occur in the skin (MARQUES et al., 2020). Sertolioma presents itself as a proliferation of elongated cells, perpendicular to the basal membrane, forming tubular structures and supported by a large amount of fibrous connective tissue (ARGENTA et al., 2016; GRIECO et al., 2008).

Regarding the treatment of testicular neoplasia, surgical treatment by bilateral orchiectomy and retroperitoneal lymphadenectomy in histologically malignant cases is suggested (COSTA, 2016). Blood transfusion is also recommended in cases of anemia and thrombocytopenia, antibiotic therapy to protect against infections and the use of anti-inflammatory drugs, if these treatments are needed (HENRIQUE et al., 2016). However, as the animal was in good clinical condition, it was directly submitted to the orchiectomy procedure, using anti-inflammatory in the postoperative period and this proved to be efficient.

In cases where there is metastatic development, oncological follow-up and chemotherapy or radiotherapy are indicated, however this treatment was not necessary in this report, since the animal did not present metastases in the follow-up exams (COSTA, 2016).

Regarding the ALT enzyme, even observing an increase of about 3 times above the reference value, this information is not significant, due to its presence in other tissues of the organism, such as heart, kidneys, muscles and erythrocytes (GIANNINI et al., 2005). However, microsomal enzymes present in hepatocytes such as cytochromes $\mathrm{P} 450$ are essential for estrogen metabolism (SANTIAGO, 2003), it is common to observe in sertoliomas the serum increase in estrogenic hormones (MARQUES et al., 2020), therefore hyperestrogenism could cause an exaggerated enzymatic activity, leading to liver damage and increased ALT, an extravasation enzyme. As soon as the tumor was removed, the enzyme levels returned to the reference values (GIANNINI et al., 2005).

The prostate enlargement secondary to sertolioma occurs due to the influence of estrogen on the prostate gland causing squamous metaplasia of the epithelium and obstruction of the prostatic ducts, predisposing to the formation of cysts, as observed in the case reported (COSTA, 2016).

Benign prostatic hyperplasia is an abnormal accumulation of dihydrotestosterone due to a high conversion of testosterone (CRUZ; ZIMMERMANN, 2017; MACPHAIL, 2014). Even with a low production of androgens, which occurs with aging, this hyperplasia can develop as long as there is an increase in the production of estrogens. Although the size increases, the secretory function of the prostate decreases (MACPHAIL, 2014). It is considered the most common prostatic disease of male dogs, not neutered, over the age of six (BAUZAITE; ANIULIENE, 2003). Therefore, it is possible that the prostatic alterations observed in this report are due to the age of the animal and the fact that he was not neutered.

Orchiectomy is the treatment of choice for benign prostatic hyperplasia, causing no side effects, resulting in a 70\% decrease in prostate size. The gland begins to shrink in days, and a palpable decrease in size is expected within 7 to 14 days (CRUZ; ZIMMERMANN, 2017). As described above in the case, where there was a reduction in prostate size from $4.40 \mathrm{~cm}$ to $2,20 \mathrm{~cm}$ in length and from $2.54 \mathrm{~cm}$ to $1.68 \mathrm{~cm}$ in height in longitudinal plane, after 6 months of performing orchiectomy. Clinical treatment can also be carried out using finasteride, a drug responsible for blocking 5-alpha-reductase leading to atrophy of the prostate parenchyma, and preventing the accumulation of dihydrotestosterone (CRUZ; ZIMMERMANN, 2017). However, as it was a case of neoplasms, this option would not be effective in treating the patient.

\section{CONCLUSION}

Based on the aforementioned content, it is possible to conclude that the thorough physical examination of the reproductive system associated with complementary exams such as ultrasound and histopathology were essential for the conclusion of the diagnosis of neoplasms and the appropriate treatment. In this report we observed the presence of two different neoplasms - seminoma and sertolioma in a non-cryptorchid dog.

\section{ACKNOWLEDGMENTS}

The authors thank the UNINGÁ - Ingá University Center, for the financing of the project, and everyone who participated directly and indirectly in the project. 


\section{REFERENCES}

ARGENTA, F. F. et al. Testicular Neoplasms in Dogs in Rio Grande do Sul, Brazil. Acta Scientiae Veterinariae, v. 44, p. 1-6, 2016.

BAUZAITE, N.; ANIULIENE, A. Enlarged prostate lesions of purêbred and mongrel dogs. Medycyna Weterynaryjna, v. 59, п. 8, p. 686-690, 2003.

BOMFIM, E. M. O. et al. Seminoma em um cão com testículo ectópico-Relato de caso. Jornal Interdisciplinar de Biociências, v. 1, p. 36-39, 2016.

CATOI, C. et al. Morphological study of testicular tumors in dogs. Lucrări ştiinłifice medicină veterinară, v. 41, p. 2-6, 2008.

CIAPUTA, R. et al. Seminoma, sertolioma, and leydigoma in dogs: clinical and morphological correlations. Bulletin of the Veterinary Institute in Pulawy, v. 56, p. 361-367, 2012.

COSTA, T. R. Neoplasia Testicular: Relato de Caso. 2016. 20 f. Monografia (Graduação em Medicina Veterinária) - Fundação Educacional Jayme de Altavila, Salvador, 2016.

CRUZ, B. P. A.; ZIMMERMANN, M. Comparação entre o tratamento clínico e cirúrgico da hiperplasia prostática benigna em cães. REVET - Revista Científica do Curso de Medicina Veterinária, v. 4, p. 13-27, 2017.

Foster, R. A. Male Genital System. In: JUBB; KENNEDY; PALMER'S. Pathology of domestic animal. 6. ed. Elsevier, 2016.

GIANNINI, E. G. et al. Liver enzyme alteration: a guide for clinicians. Canadian Medical Association or its licensors, v. 172, n. 3, p. 367-379, 2005.

GRIECO, V. et al. Canine testicular tumours: a study on 232 dogs. Journal of comparative pathology, v. 138, n. 2-3, p. 86-89, 2008.

HENRIQUE, F. V. Sertoli cell tumor and diffuse seminoma in dog with bilateral cryptorchidism - Case report. Brazilian Journal of Veterinary Medicine, v. 38, p. 217-221, 2016.
LOPES, C. E. B. Diffuse sertolioma in a criptorquidic dog. Ars Veterinaria, v. 35, p. 021-025, 2019.

MACPHAIL, C. M. Surgery of the reproductive and genital systems. In: FOSSUM, T. W. Small animal surgery. 4. ed. Rio de Janeiro: Elsevier, 2014.

MADUREIRA, R. et al. Seminoma and sertolioma in a male pseudohermaphrodite dog with unilateral cryptorchidism. Semina: Ciências Agrárias, v. 38, p. 2-7, 2017.

MARQUES, B. A. S. et al. Sertolioma in dog associated with cryptoquidism: report case. Revista de Educação Continuada em Medicina Veterinária e Zootecnia do CRMV-SP, v. 18, p. 1-6, 2020.

MORRIS, J.; DOBSON, J. Trato Genital p. 175-178. In: MORRIS, J.; DOBSON, J. Oncologia em pequenos animais. São Paulo: Roca, 2001 .

NETA, J. H. et al. Sertolioma in a Canadian Husky: Relationship between Tumor, Hormones, Neurons and Skin. Acta Scientiae Veterinariae, v. 47, n. 416, p. 1-6, 2019.

SANTIAGO, L. M. A. Metabolism in the cytochrome $\mathrm{P} 450$ system and its importance in general practice. Revista Portuguesa de Clínica Geral, v. 19, p. 121-129, 2003.

SANTOS, R. L. et al. Testicular tumors in dogs: frequency and age distribution. Arquivo Brasileiro de Medicina Veterinária e Zootecnia, v. 52, n. 1, p. 25-26, 2000

SILVA, W. P. N. et al. Concomitant leydigocytoma and seminoma in a dog - Case Report. Acta Veterinaria Brasilica, v. 8, p. 132-135, 2014.

STAUT, J. L.; ASSEF, M. L. M.; CIRIO, S. M. Estudo histoquímico da matriz extracelular de neoplasias testiculares de cães (Canis Familiares Linnaeus, 1758). Estudos de Biologia, v. 29, п. 68-69, p. 242-247, 2007.

VISCONE, E. A. et al. Seminoma and interstitial cell tumor in the same testicle as a dog - Case Report. Enciclopédia biosfera, Centro Científico Conhecer, v. 13, p. 919-923, 2016. 